\title{
Word Order and Poetic Style: Auxiliary and Verbal in The Metres of Boethius
}

\section{Citation}

Donoghue, Daniel. 1986. Word order and poetic style: Auxiliary and verbal in The Metres of Boethius. Anglo-Saxon England 15: 167-196.

\section{Published Version}

doi:10.1017/S0263675100003756

\section{Permanent link}

http://nrs.harvard.edu/urn-3:HUL.InstRepos:3627678

\section{Terms of Use}

This article was downloaded from Harvard University's DASH repository, and is made available under the terms and conditions applicable to Other Posted Material, as set forth at http:// nrs.harvard.edu/urn-3:HUL.InstRepos:dash.current.terms-of-use\#LAA

\section{Share Your Story}

The Harvard community has made this article openly available.

Please share how this access benefits you. Submit a story.

\section{Accessibility}




\title{
Word order and poetic style: auxiliary and verbal in The Metres of Boethius
}

\author{
DANIEL DONOGHUE
}

The Metres of Boetbius offer a unique opportunity to study the complex subject of Old English verse syntax. They enjoy this distinction because of the unusual way in which they were composed. The versifier did not work directly from the original Latin metra of Boethius's Consolation of Pbilosophy but from an Old English prose intermediary, freely translated from the Latin originals. King Alfred was the author of the prose translation and was probably also responsible for turning the parts of the prose corresponding to the Latin metra into Old English verse. Since a copy of the prose model survives, it affords us an opportunity to compare the two versions in order to judge the versifier's debt to the prose. ${ }^{1} \mathrm{He}$ apparently followed it quite faithfully and without referring back to the Latin originals. ${ }^{2}$ In many verse passages one can find words and half-lines which are direct transcriptions from the prose. Consequently the Old English Metres are generally considered nothing more than prose expanded into verse, adding only 'poetic' embellishments (like repetition and variation) and obvious morals drawn from the passage. The fruit of the versifier's labours may be uninspired poetry, but the way that he rearranged the words of the prose offers a rare glimpse into the more elusive

1 A copy of the prose model is preserved in Oxford, Bodleian Library, Bodley 180 (B). The manuscript which contains the alternating Old English verse and prose is London, British Library, Cotton Otho A. vi (C). In the latter half of the seventeenth century Franciscus Junius made a transcription ( $\mathrm{J}$ ) of both manuscripts, which is now housed in the Bodleian Library as Junius $\mathrm{x}$. Since the fire of $173 \mathrm{I}$ left $\mathrm{C}$ severely damaged, $\mathrm{J}$ is of great use in reconstructing the original text.

2 Only one verse passage adds anything of substance to the prose, and it seems to have been taken from a Latin commentary. The verse passage is Metre xx. 166a-175a. A marginal note in one Latin commentary reads 'caelum et terram mareque in modum ovi figurari'. Presumably on the basis of this simile the versifier added a short description of the earth, comparing its shape with the shape of an egg. On the use of commentaries, see Georg Schepss, 'Zu König Alfreds Boethius', ASNSL 94 (1895), 149-60, and Brian S. Donaghey, 'The Sources of King Alfred's 'Translation of Boethius's De Consolatione Philosophiae', Anglia 82 (1964), 23-57, at 30-1. A recent study by Joseph S. Wittig ('King Alfred's Boetbius and its Latin Sources: a Reconsideration', ASE II (1983), I57-98) has thrown doubt on the traditional beliefs about the extent to which the author of the prose translation relied on Latin commentaries, but it does not address the question of the possible influence on this particular verse passage. 


\section{Daniel Donoghue}

conventions of verse-making. Since the many similarities make the differences quite pronounced, the poetical shortcomings of the Metres may be a blessing. A mediocre versifier is more likely to compose mechanically and to imitate established patterns than a good poet, whose virtuosity often conceals the rudiments of his craft.

In the following pages I investigate the word order of auxiliaries and verbals in The Metres of Boetbius. ${ }^{3}$ The method is adapted from one first used by Alan Bliss in 'Auxiliary and Verbal in Beowulf'. ${ }^{4}$ To supplement Bliss's method, however, I also make direct comparisons of the prose with the verse when the opportunity arises. Such comparisons are particularly useful since the principles of prose syntax are on the whole better understood than the principles of verse syntax. By examining how individual passages in the Metres differ from the corresponding passages in the prose model, I am able to determine with some confidence which usages are distinctly 'poetic' and which are common to prose. I begin with an examination of metrical constraints that affect all auxiliaries regardless of the grammatical function of the clause. Next I consider the behaviour of auxiliaries in clauses unambiguously principal or dependent and find that the auxiliary's stress and position in the word order follow distinct patterns in each kind of clause. These patterns are quite different from the ones that Bliss observed in Beowulf, where the grammatical function of the clause has very little effect on the behaviour of the auxiliary. The results for 'unambiguous' claùses provide a means for determining the grammatical function of clauses of doubtful status; that is, clauses which may be either dependent or principal. Finally I suggest the possibility of using the distinctive patterns of behaviour of auxiliaries in Beowulf and the Metres as a

3 I wish to thank Alan Bliss, who first aroused my interest in Old English syntax and assisted me at every stage of this project. I also wish to thank Fred C. Robinson for his valuable advice and encouragement, John C. Pope, who kindly suggested numerous improvements, and R. Allen Shoaf, who helped put this paper in final form. The shortcomings that remain are my own.

All quotations from and references to the Metres are taken from The Paris Psalter and the Meters of Boethius, ed. George Philip Krapp, The Anglo-Saxon Poetic Records ; (New York and London, 1932). Each reference gives the number of the Metre in roman capitals followed by arabic numerals indicating the line. (Krapp used arabic numerals for both.) Quotations from and references to the prose are taken from King Alfred's Old English Version of Boetbius De Consolatione Philosopbiae, ed. Walter John Sedgefield (Oxford, 1 899; repr. Darmstadt, 1968). Each page and line reference to the prose is in arabic numerals, which indicate the starting point of the clause in question. The prose line reference does not necessarily indicate the portent of the clause. The abbreviations in Sedgefield's edition are silently expanded, and I have omitted from both editions the editorial signals for insertions, emendations and transitions from $\mathrm{C}$ to $\mathrm{J}$. Other editions of the verse which $\mathrm{I}$ refer to include Sedgefield's (ibid.); Die Altengliscben Metra des Boetius, ed. Ernst Krämer (Bonn, 1902); and Die Handscbrift von Exeter, Metra des Boetius, Salomo und Saturn, Die Psalmen, ed. Bruno Assmann (Leipzig, 1898), pp. 247-303. ${ }_{4} A S E 9$ (1981), 157-82.
Word order and poetic style: 'The Metres of Boethius'

way to distinguish two Old English verse styles, which I tentatively call 'epic' and 'lay'. The 'lay' tradition may have preserved archaic uses later modified or discarded in the 'epic' tradition.

By concentrating on auxiliaries I avoid the vexed problem of whether finite verbs can be stressed words regardless of their position in the clause or whether they are particles that receive a stress only when they are displaced from the metrical dip immediately preceding or following the first stressed word of the clause. All metrists seem to agree that auxiliaries, because of their lack of significant meaning, do not receive a stress unless they are displaced from the metrical dip. ${ }^{5}$ While the degree of stress on auxiliaries can vary, their dependent verbals in the Metres always bear a stress. ${ }^{6}$

There is another advantage in examining only clauses with an auxiliary and verbal. It can be seen most clearly in prose clauses, where syntactical analysis is not as problematical as it is in verse. If one distinguishes the sentence elements subject $(\mathrm{S})$, verb $(\mathrm{v})$ and object $(\mathrm{O})$, they generally fall into three word orders: common $(\mathrm{SvO})$, demonstrative (vSO) and conjunctive (SO. . .v). ${ }^{7}$ Since the relative positions of $\mathrm{S}$ and $\mathrm{O}$ remain constant, the three types are most easily distinguished by the position of the verb: in common word order the verb falls between $\mathrm{S}$ and $\mathrm{O}$, in demonstrative it comes before $\mathrm{S}$ and $\mathrm{O}$ and in conjunctive it has final position. The distinction becomes obscured, however, when either $\mathrm{S}$ or $\mathrm{O}$ is absent; not every verb takes an object, and the subject or object may

5 The question of particles is treated more thoroughly below, pp. 172-3. On the question of stress on auxiliaries, see Hans Kuhn, 'Zur Wortstellung und -betonung im Altgermanischen', BGDSL 57 (1933), $1-109$, at 52-7; he stated that although finite verbs in dependent clauses are more frequently stressed than those in principal clauses, auxiliaries in each kind of clause are often unstressed. See also A. J. Bliss, The Metre of Beonulf (Oxford, 1958; rev. ed. 1967), §12. Spencer Cosmos ('Kuhn's Law and the Unstressed Verbs in Beowulf', Texas Stud. in Lit. and Lang. 18 (1976), 306-28) distinguished between auxiliaries and 'fully lexical finite verbs' precisely on the grounds that the latter normally occupy 'positions of metrical prominence'. More recently Calvin B. Kendall ('The Metrical Grammar of Beowulf: Displacement', Speculum 58 (1983), 1-30) has argued that not only auxiliaries but also many alliterating finite verbs lack a full metrical stress. See also W. P. Lehmann and Takemitsu Tabusa, The Alliterations of the Beowulf (Austin, Texas, 1958), p. 6.

6 By 'verbal' I mean a dependent infinitive or past participle; present participles and inflected infinitives preceded by to are automatically excluded. When there are two verbals only the first is considered, even if one is grammatically dependent on the other, as in the line, "par he wolde a winnan onginnan' (xxv.69). E. G. Stanley ('Verbal Stress in Old English Verse', Anglia 93 (1975), 307-34, esp. 322-4), noted that infinitives are occasionally unstressed in other Old English poems, but the proportion is quite small.

The terms 'common', 'demortstrative' and 'conjunctive' come from S. O. Andrew, Syntax and Style in Old English (Cambridge, 1940). See also Bliss's preliminary remarks, 'Auxiliary and Verbal', pp. $157^{-63}$, where he discusses in more detail a number of points only briefly considered here. Bruce Mitchell's Old English Syntax, 2 vols. (Oxford, 1985 ), which came out after the completion of this paper, takes up these matters at $\$ 3887-902$ and $\$ 3944-7$. On rare occasions $\mathrm{O}$ precedes $\mathrm{S}$ and v; e.g. 'and hire saule mon sceolde læedan to helle' (Sedgefield 102.1). 


\section{Daniel Donogbue}

be understood from a previous clause. In some cases, for instance, it may be impossible to distinguish between common $(\mathrm{Sv}[\mathrm{O}])$ and conjunctive (S[O]v) word orders. This difficulty can be avoided to some extent, however, if one considers clauses where the finite verb is an auxiliary that takes a verbal. The position of the verbal (V) in the word order is fixed in relation to the subject and object, and once again three word orders can be distinguished on the basis of the verb's position: common (SvOV), demonstrative (vSOV) and conjunctive (SO. . Vv). Thus every clause in prose can be classified according to the position of the auxiliary with respect to the verbal ( $\mathrm{vV}$ or $\mathrm{Vv}$ ) even if other sentence elements are absent, and this distinction applies equally to verse clauses.

The positions possible for each auxiliary in the word order of Old English verse are limited by certain constraints, of which some apply to all finite verbs and one affects auxiliaries alone. Prominent among these constraints are Kuhn's two laws. ${ }^{8}$ Kuhn divided the words in a verse clause into three categories: stress-words, proclitics and particles. Stress-words always bear a strong stress; they include nouns, adjectives, verbals and some adverbs. Proclitics are closely dependent on the following stress-word and are therefore unstressed; they include prepositions, demonstratives and possessives. Particles do not naturally carry a strong stress and are not subordinate to any word; they include finite verbs, demonstrative adverbs, personal pronouns, demonstrative pronouns and some conjunctions. According to Kuhn's First Law (Satzpartikelgesetz) $)^{9}$ all unstressed particles in a clause must be grouped together in a dip either before or immediately after the first stressed word; they must not be distributed both before and after the first stressed word; and they must not be placed after an initial stressed word preceded by a proclitic or an unstressed prefix. In some passages of the Metres the effect of Kuhn's First Law on the position of the verb can be seen in the transition from prose to verse. In the prose clause 'forðampe nan ðara gesceafta ne mæg bion buton oðerre ...' (80.35) the verb is placed, quite properly for prose syntax, after the subject. But in verse unstressed particles must be grouped together, so the versifier rearranged the word order to create an initial dip (and eliminated the conjunction fordampe): 'Ne mæg hira ænig butan oðrum bion' (xx.145). The auxiliary is drawn to the beginning of the clause, before the subject.

Kuhn's Second Law (Satzspitzengesetz) $)^{10}$ states that if a clause begins with a dip, the dip must contain a particle; a proclitic or an unstressed prefix alone cannot precede the first stressed word. Once again it is possible to trace how the poet observed this law in composing the verse from the prose model. In the

$$
8 \text { See his 'Zur Wortstellung und -betonung'. } \quad 9 \text { Ibid. pp. 8-Io. } \quad{ }^{10} \text { Ibid. pp. 43-5. }
$$

Word order and poetic style: 'The Metres of Boethius'

following prose passage the verb appears after the subject: 'ac se anwealda hæfð ealle his gesceafta swa mid his bridle befangene' (49.2). When this clause was rendered into verse, the initial conjunction disappeared and the auxiliary was moved to the beginning of the clause so that the proclitic se is not the only word preceding alwealda: 'Hæfð se alwealda ealle gesceafta / gebæt mid his bridle' (xI.22-3a).

Kuhn's two laws govern the position of particles, which are normally unstressed. A particle displaced from the dip at the beginning of a clause receives a positional stress and is treated as if it were a stress-word. When the displaced particle is a verb, however, it falls under another constraint, which Eduard Sievers formulated into the Rule of Precedence. ${ }^{11}$ This rule states that a verb may not take precedence in alliteration over a noun; therefore an auxiliary may not carry the alliteration in a half-line which also contains a noun.

Another constraint recently observed by Bliss ${ }^{12}$ affects only auxiliaries, and its effect depends on whether the auxiliary is mono- or disyllabic. However, Bliss's two-fold division requires some qualifications. An unstressed prefix may be added to the auxiliary without a change in its metrical value; similarly a negative proclitic does not change the metrical value. Thus ongind and ne ongind are considered monosyllabic, and ne ongunnon disyllabic. A number of auxiliaries consist of two syllables, the first of which is short (such as bafad, magen and scylen). When they bear a stress they may be subject to metrical resolution, but not always. Bliss noticed that in Beowulf, whether or not there is resolution, they follow the same distribution as that of monosyllabic auxiliaries, a distribution quite distinct from that of disyllabic auxiliaries. Likewise in the Metres their distribution follows that of monosyllabic auxiliaries. Following Bliss therefore I consider all such auxiliaries monosyllabic, whether or not resolution applies.

Of the 343 auxiliaries in the Metres 212 are monosyllabic (according to this broader classification) and 131 are disyllabic. ${ }^{13}$ The great majority of the monosyllabic auxiliaries stand in the first half-line of the clause, in accord with Bliss's observation for Beowulf. Only twenty-five appear in a later half-line. ${ }^{14}$

11 Altgermanische Metrik (Halle, 1893 ), $\$ 22-9$. In $\$ 24$ he admitted some exceptions.

12 'Auxiliary and Verbal', pp. 160-2.

13 My count of auxiliaries does not include those where an infinitive is understood and excludes one auxiliary which is the second member of a pair: 'wilt oððe most' (xxIv. 56a). Two trisyllabic auxiliaries are included among the disyllabic: tiliad (x.22b and xr.79b) and wilnige (xxIX.1a).

14 Seven of the 'later' auxiliaries combine with a verbal to form a half-line and will be discussed below, pp. 177-82; another four (mage (vir.32b), sceal (xx.197b) and mag (xxI.38b and Xxir. $13 \mathrm{~b}$ )) are breaches of Sievers's Rule; another two (ne magon (xxv.59a) and meabt (xxvi.107b)) are unstressed in breach of Kuhn's First Law. The other twelve are variously distributed. 


\section{Daniel Donogbue}

Disyllabic auxiliaries are more evenly distributed: seventy-one in the first halfline and sixty in a later half-line. Most of those in a later half-line (forty-five) combine with a verbal to form a complete half-line. ${ }^{15}$ Thus an auxiliary's position in the word order can vary according to the number of syllables which it has.

All verse clauses can be categorized according to the grammatical function of the word with which they begin. ${ }^{16}$ If one excludes initial auxiliaries (which are unstressed in the Metres ${ }^{17}$ and constitute a special category), the remaining clauses fall into three groups: (I) principal clauses, which begin with an unstressed particle or a stressed word; (2) dependent clauses, which begin with a conjunction or a relative pronoun; (3) clauses of doubtful status, which begin with a word of uncertain grammatical function. An initial $p a$, for instance, may be an adverb or a subordinating conjunction (or a relative pronoun), but there is no consistent and objective means of determining when it begins a principal verse clause (that is, when it is the adverb, 'then') or when it begins a dependent clause (that is, when it is the conjunction, 'when'). ${ }^{18}$ Comparison with the prose is particularly helpful with such clauses in the Metres.

Principal clauses and dependent clauses in the verse stand in two different relationships to the prose model in the matter of initial words. In the prose most of the initial words of clauses, whether principal or dependent, are conjunctions or words such as $p a$ which may be conjunctions. In the verse on the other hand only dependent clauses, as we have seen, begin with conjunctions: principal clauses begin with an unstressed particle (such as a

15 Two 'later' disyllabic auxiliaries are unstressed in breach of Kuhn's First Law: willad (v.22a) and wolde (Ix. 1 2a). The latter is discussed below, p. 176.

16 I consider the starting point of a clause to be the first word which performs a grammatical function in the clause. Expletives such as bwat and eala and words used in direct address are outside the clause. On many occasions Kuhn's First Law seems to justify this treatment. According to the law a clause can have only one metrical dip either before or immediately after the first stressed word. In the passage 'Eala, min drihten, pret pu eart ælmihtig' (xx. I) there is a dip before the first stressed word of the second half-line. The poet treated this line as if it contained two clauses, or rather, as if pat began the clause anew.

17 With one exception, 'hat eft cuman' (xxIx.83 b), where the alliteration falls on $b$. Clauses with initial auxiliaries are discussed below, p. 175.

18 Other initial words of uncertain grammatical function in the Metres include ar, ardam, forbwam, fordam, fordy, bu, bwa, bwar, bwaper, nu, se, sio, siddan, swa, para, pam, par, pat, ponne and $\not p y$. Bliss observed, 'The clauses of doubtful status constitute a central problem in the study of Old English verse syntax; until it is solved the preference of an Anglo-Saxon poet for parataxis or hypotaxis must remain a matter of conjecture' ('Auxiliary and Verbal', p. 166). S. O. Andrew in Syntax and Style in Old English and later in Postscript on 'Beowulf' (Cambridge, 1948) took up the question of clauses of doubtful status in great detail, although his conclusions have not met with wide approval; see, e.g., the reviews of the former by $\mathrm{H}$. Larsen (JEGP 4 I (1942), 85-8), A. Macdonald (RES 17 ( I 941), 499-50I) and Simeon Potter (MLR 36 (1941), 252-5) and that of the latter by Kemp Malone (ES 32 (1951), 116-19).
Word order and poetic style: 'The Metres of Boethius'

personal pronoun) or a stressed word. Hence, by removing initial particles the versifier often converted dependent prose clauses into principal verse clauses, a tendency which accords well with the current scholarly consensus that verse is more paratactic than prose. In a dependent verse clause, however, an initial conjunction usually corresponds to a conjunction in the prose but not necessarily the same one. For instance, the subordinating conjunction peab is used in the verse in place of ponne (46.5), and (60.30), $n u(80.23)$ and $p e$ (105.2 I) in the prose.

Auxiliary-and-verbal pairs fall into three word orders determined by the position of the auxiliary in relation to the verbal and by the presence or absence of stress on the auxiliary. In the first word order the auxiliary is unstressed and before the verbal $(\mathrm{vV})$; in the second it is stressed and before the verbal ( $\mathrm{v} \mathrm{V})$; and in the third it is stressed and after the verbal (Vv́). ${ }^{19}$ Since a verbal is never the first word of a clause in the Metres, the auxiliary cannot follow the verbal and remain unstressed. The total distribution for all auxiliaries and verbals in the Metres is vV II 5, v́V 144 and Vv́ 84.

When the auxiliary is initial it remains unstressed (with one exception, bat (xxIx. $83 \mathrm{~b}$ )). ${ }^{20}$ In most cases (thirty-eight out of fifty-three) the clauses which auxiliaries introduce are principal, but a significant number (fifteen) introduce asyndetic co-ordinate clauses. Initial auxiliaries occupy a special category with regard to the relation between word order and the grammatical function of a clause. Because the clauses they begin can be either principal or dependent, they can shed no light upon the crucial problem of clauses of doubtful status.

So one must turn to clauses which begin with a word other than the auxiliary in order to examine the relation between word order and grammatical function. The first clauses to be considered are the fifty-five which are unambiguously principal. ${ }^{21}$ Their distribution is $\mathrm{vV} 29, \quad$ v́ 17 and V'́ 9. Forty-six auxiliaries fall before the verbal, yet the total number of stressed

19 See Bliss, 'Auxiliary and Verbal', pp. 157-9.

20. An auxiliary begins a clause in the following half-lines: (a) asyndetic coordinate clause, 1.42a, I. 59 b, I.66b, 1.70a, 1.82b, xIII.28b, xx.144a, xxIv.8a, xxIv. I Ib, xxIV. 1 7a, xxv.19a, xxv.64a, XXVI.72a, XXVI.79b and XxIx.83 b; (b) subject pronoun, v. $5 \mathrm{a}$, v. $29 \mathrm{~b}, \mathrm{x} .38 \mathrm{a}$, xIII. $33 \mathrm{a}$, xIV.9a,

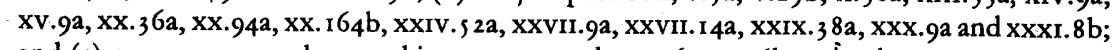
and $(c)$ noun or noun phrase subject, I. 22a, I.3 Ib, IV.46a, vir.6b, vir. I Ib, vir.1 8a, virr. $33 \mathrm{a}$,

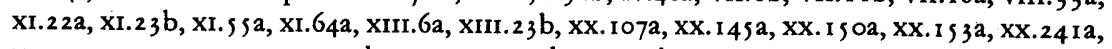
XXVI. 5 Ia, XXVI.90a, XXVI. I 3 b, xxix.34a and XxxI.1 2 b.

21 Auxiliaries in principal clauses occur in the following half-lines: $(a)$ initial stressed word, I.I Ib, I.I8b, I.28b, V.I8b, V.19b, vi.4b, vII.13b, X.7b, xI.65b, xIIr.37b, xx.79a, xxv.49b, xxv. $99 \mathrm{a}$, xxvI.84b, xxvI.8 5 b, xxvi.107b, xxvIr.2 1a, xxIx.86b and xxIx.88a; and $(b)$ initial unstressed particle, Proem 8b, I.72b, I.76b, II.4b, IVI 7 b, v.1a, v.1 8a, v.26b, v.28a, virI. 2b, IX.9a, IX.I 2a, IX.45b, X.52a, XI.29a, xIr.22a, xIII.1a, xIIr.79a, xIX.1 7b, XX.34a, XX.200a, xx.219a, xxII. 58 b, xxIII.7a, xxIv.15a, xxIv.26b, xxIV.50b, xxIv. 5 b, xxv.37b, xxv.45b,

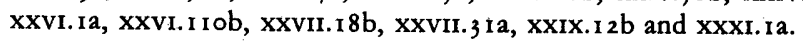




\section{Daniel Donoghue}

auxiliaries (twenty-six) is almost the same as unstressed (twenty-nine). The following examples are typical for principal clauses: 'scir bið gedrefed, / burna geblonden' (v. I 8b-1 ga) and 'He hine inne heht / on carcernes cluster belucan' (I. $72 \mathrm{~b}-73$ ). The nine instances of the third word order (V'́) ${ }^{22}$ follow a uniform pattern: in five cases the auxiliary forms a half-line with the dependent verbal, and in the other four the initial half-line consists of a subject pronoun + verbal t auxiliary. These will be discussed below (pp. 177-82).

In contrast to the pattern for principal clauses, only six of the eighty-eight dependent clauses have unstressed auxiliaries. ${ }^{23}$ The totals of the three word orders are $\mathrm{vV} 6, v^{\prime} \mathrm{V} 46$ and $\mathrm{Vv}^{\prime} 36$. The auxiliary is before the verbal a few more times than after (fifty-two to thirty-six). Typical examples are 'ac on selfwille sigan lætest' (IV.50) and 'peah anra hwilc wið oðer sie / miclum gemenged' (xx.65-6a). Three of the six auxiliaries in the first word order (vV)24 appear in clauses introduced by se pe. They form an exception to the rule for dependent clauses for reasons explained below (pp. 182-6).

These results clearly show that in dependent clauses the position of the auxiliary with respect to the verbal is of little importance as long as the auxiliary is stressed. What apparently distinguishes a principal clause is the position of the auxiliary; what distinguishes a dependent clause is a stressed auxiliary. Consequently a stressed auxiliary before the verbal is a word order common to both kinds of clauses. A glance at the total distribution for the three word orders ( $\mathrm{VV}$ i is, $\mathrm{v}^{\mathrm{V}}$ I 44 and $\mathrm{V}$ v 84) will show that the second word order is the most numerous for all clauses, including clauses of doubtful status and clauses with an initial auxiliary. If the fifty-three initial auxiliaries are

22 The nine auxiliaries in the third word order are sceal (IV. $17 \mathrm{~b}$ ), wyrd (V.1 8a), scealt (v.26b), sceolde (Ix.45b), meabt (xIx.17b), mag (xxv.37b), wile (xxIx.1 2b), sceolden (xxIx.86b) and sceoldon (xxIx.88a). On the suggestion of Professor Bliss, I have emended the punctuation of rv. 17 so that the clause begins 'He gongan sceal' rather than 'geara gehwelce'. The clause preceding 'He gongan sceal' makes perfectly good sense when 'geara gehwelce' ends it. For a parallel, see XIX.27.

23 Auxiliaries in dependent clauses occur in the following half-lines: (a) with a coordinating

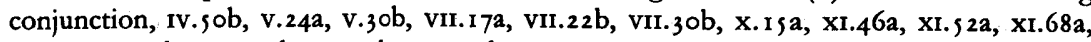
xI.70b, xI.75b, xIII.27b, xIV.4b, xIx.40b, xx.72a, xx.139a, xx.257b, xxI.35b, xxIII.6b, XxIV.4a, xxIV. $53 \mathrm{~b}, \mathrm{xxvI.80b}$ and $\mathrm{xxx} .12 \mathrm{a}$; and $(b)$ with a subordinating conjunction,

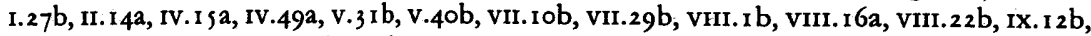
IX.2 Ia, IX. 27 b, IX. 53 a, IX. 58 b, X.2b, X.1 2a, X.27a, X.39b, X.69b, XI. $56 \mathrm{~b}$, xI.79b, xI.80a, XI.98b, xII.1a, xIII.32b, xIII.35b, xIIr.4ib, xIV.7a, xVI.1a, xVI.3b, xVI.8b, xVI.19b, xVIr.23b, xvir. 9 b, xx.21b, xx.65b, xx.70b, xx.11.5b, xx.128a, xx.129b, xx.244b, xxI.5a, xxI.38b, xxII.Ib, xxII.19b, xxII.37a, xxII.42b, xxII.9ob, xxII. $2 \mathrm{~b}$, xxII. $56 \mathrm{~b}$, xxIII.2b, xxIv.6a, xxIv.46b, xxv.22a, xxv.72b, xxvI.46a, xxvi.69a, xxvI.102b, xxIX. Ia, xxIX. $32 \mathrm{~b}, \mathrm{xxx}$. I $\mathrm{b}$ and xxxI.Ib.

24 The six auxiliaries in the first word order are sceal (vIr.30b), mag (x.1 2a), sceal (xI. s 2a), wille (xIr.Ia, with accidental alliteration), wille (xvI. Ia) and bid (xxIr.37a). The clauses containing mag and $b i \delta$ (x.1 2a and xxir.37a) each begin with the second peab of a peab ... peab pair and must be construed as principal.
Word order and poetic style: 'The Metres of Boethius'

excluded from the count, the proportion of clauses with the second word order is even greater. The first and third word orders seem to be reserved almost exclusively for principal and dependent clauses respectively. Thus the behaviour of auxiliaries in the Metres offers a consistent means of determining in many cases whether a clause is principal or dependent.

$$
\begin{aligned}
& \text { SPECIFIC INVESTIGATIONS OF WORD ORDER IN THE METRES } \\
& \text { Verbal-auxiliary balf-lines }
\end{aligned}
$$

The fifty-three half-lines composed of a verbal and auxiliary deserve special attention because they provide a clue for explaining exceptions to the usual word order in principal clauses. 25 While most verbal-auxiliary half-lines appear in dependent clauses, a fairly large proportion appears in principal clauses. Therefore the following discussion will examine the auxiliaries in these halflines apart from the grammatical function of the clause. The total distribution over the three word orders is $\mathrm{vV} 2, \mathrm{v} V 8$ and $\mathrm{Vv}$ 43. Only two auxiliaries are unstressed (see below) and only ten precede the verbal. Another important characteristic, which is not apparent from the distribution, is that forty-six out of fifty-three auxiliaries are disyllabic. Almost every disyllabic auxiliary in the third word order ( $\left.V_{v}^{\prime}\right)$ is found in a verbal-auxiliary half-line; only five such auxiliaries do not make up a half-line with the verbal. Monosyllabic auxiliaries in the third word order, on the other hand, are usually found in the first halfline of a clause with other sentence elements. Most verbal-auxiliary half-lines are $b$ verses; that is, they constitute the second verse of a full line. Only eleven are $a$ verses. Finally, verbal-auxiliary half-lines fall within a small number of metrical types, as table I shows. ${ }^{26}$

$$
\text { TABLE I }
$$

\begin{tabular}{cc}
\hline \hline Metrical type & Frequency \\
\hline $2 \mathrm{~A}$ & 26 \\
$2 \mathrm{C}$ & $\mathrm{II}$ \\
$\mathrm{IA} / \mathrm{IA}^{*}$ & 9 \\
$3 \mathrm{~B} / \mathrm{BB}^{*}$ & 5 \\
$\mathrm{al}$ & 2 \\
\hline
\end{tabular}

25 Henceforth I call these half-lines verbal-auxiliary half-lines; they are I.27b, I.3 Ia, I.39a, I.62 b,

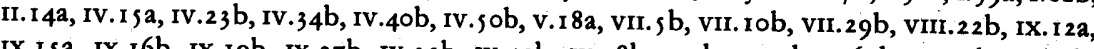
IX.1 sa, IX.I6b, IX.19b, IX.27b, IX.35b, IX.45b, IX.58b, X.2b, X.22b, X.64b, XI.28b, XI.7ob, xI.75b, xI.79b, xI.98b, xIII.27b, xVI.19b, xvirI.9b, xIx.25a, xIx.32b, xix.40b, xx.102b, xx.273b, xxIIr.6b, xxIv.37b, xxIv.46b, xxv.72b, xxvI.18b, xxvI.72a, xxvI.80b, xxvI.82b, Xxvr.104a, xxvir.7a, xxIx.I $2 \mathrm{~b}$, xxIX.39b, xxIx.86b and xxIx.88a.

${ }^{26} \mathrm{I}$ follow the method of scansion used by Bliss in The Metre of Beowulf. 


\section{Daniel Donogbue}

One out of every two half-lines belongs to type 2A. Some important consequences of the relative frequencies of the metrical types will become apparent later in this discussion. The following example will serve to illustrate the more common characteristics of a verbal-auxiliary half-line: 'pe mete oððe drinc mængan cuðe' (vIII. 22). The auxiliary is disyllabic, stressed and after the verbal. The half-line containing the auxiliary appears in a dependent clause, and constitutes a $b$ verse of metrical type $2 \mathrm{~A}$.

Only one verbal-auxiliary half-line begins a clause: 'mynton forlatan leofne hlaford' (xxvi.72). Some metrists might consider mynton stressed because it carries more semantic weight than most other auxiliaries. However, there are two reasons to argue against stress: (a) mynton, unlike the first word of most verbal-auxiliary half-lines, does not alliterate and $(b)$ initial auxiliaries are usually unstressed. Perhaps another alternative is to attribute partial stress to mynton. Only one other verbal-auxiliary half-line in the Metres has an unalliterating auxiliary as the first element: 'He for unsnyttrum / wolde fandian' (IX. I rb-1 2a). Here it is tempting to consider wolde stressed in order to avoid a violation of Kuhn's First Law, but stress is difficult to justify in the absence of alliteration. The only way to correct the alliteration is to emend the passage, and the simplest emendation would be a transposition to "*fandian wolde', which yields a half-line with regular metre and alliteration and a clause with smooth syntax. However, there are insufficient grounds for an emendation. In any case neither half-line throws any light on the other. Both appear to be anomalous. ${ }^{27}$ In the following discussion I consider both mynton and wolde to be unstressed. I realize, however, that any scansion of these lines will be unsatisfactory in some way.

The auxiliaries wolde and mynton (Ix. I $2 \mathrm{a}$ and XXVI.72a) are the only instances where the first word of a verbal-auxiliary half-line does not alliterate. In most cases the alliterating word is the verbal, but in the eight half-lines of the second word order $\left(v^{\prime} \mathrm{V}\right)$ the auxiliary alliterates. In all of Beowulf there is only one verbal-auxiliary half-line with an alliterating auxiliary. Bliss noted, 'it represents a breach of Sievers's Rule of Precedence, by which a finite verb does not take precedence in alliteration over a noun' ${ }^{28}$ The eight similar auxiliaries in the Metres represent breaches of the same rule. ${ }^{29}$ They are 'meahte asettan'

27 D. Slay discussed similar instances of displaced but unalliterating verbs ('Some Aspects of the Technique of Composition of Old English Verse', TPS 1952 , I-14, at I3-14). He called them 'mistakes' with no 'mitigating circumstances' to explain the unusual position for the verb.

28 'Auxiliary and Verbal', p. $162, \mathrm{n} .18$. The half-line in Beowulf is $1728 \mathrm{~b}$, where transpositon may be called for: '*hwilum he lateð on lufan hworfan'.

29 Breaches of Sievers's Rule are not limited to verbal-auxiliary half-lines. Other auxiliaries include mage (VIr. $32 \mathrm{~b}$ ), sceal (XX.1 97b) and mag (XXI.38b and xxII. I $3 \mathrm{~b}$ ). This count does not include other finite verbs. In fact Sievers singles out the Metres as a poem that allows 'zahlreiche Verstösse' of his Rule (\$29).
Word order and poetic style: 'The Metres of Boethius'

TABLE 2

\begin{tabular}{cccc}
\hline \hline Word order & $\begin{array}{c}\text { Monosyllabic } \\
\text { auxiliary }\end{array}$ & $\begin{array}{c}\text { Disyllabic } \\
\text { auxiliary }\end{array}$ & Total \\
\hline vV & - & al & 2 \\
vV & IA & $\mathrm{IA}^{* a}$ & 8 \\
V & $3 \mathrm{~B} / \mathrm{BB}^{*}$ & $2 \mathrm{~A} / 2 \mathrm{C}^{b}$ & 43 \\
Total & 7 & 46 & 53 \\
\hline \hline
\end{tabular}

a Five instances of type $\mathrm{IA}^{*}$ and only one of type 2A: 'meahte weorðan' (XI.98b) $b$ Thirty-six half-lines are of metrical types $2 \mathrm{~A}$ or $2 \mathrm{C}$, and only two instances of $\mathrm{IA}^{*}$; see n. $3 \mathrm{I}$.

(VII. 5b), 'wille onlæten' (xI.28b), 'wile onlatan' (xI.75b), 'meahte weorðan' (xI.98b), 'wille gepencan' (xIIr.27b), 'sindon gehydda' (xIx.32b), 'weorðað gepawened' (xx.102b) ${ }^{30}$ and 'mæg aweorpan' (xxIrr.6b). The half-lines show surprising uniformity: all are $b$ verses, where alliteration is limited to the first word; three auxiliaries are forms of mag and three are forms of willan; all but one of the verbals have an unstressed prefix. In the seven half-lines where the verbal has a prefix, the metrical type must be iA or I $\mathrm{A}^{*}$; the other half-line is $2 \mathrm{~A}$. Metrical types $I A$ and $I A^{*}$, in fact, are quite rare outside the second word order. ${ }^{31}$ Since type $2 \mathrm{~A}$, the most common type for all verbal-auxiliary halflines, applies to only one of these eight, it seems likely that some connection exists between the second word order and types iA and $\mathrm{IA}^{*}$.

Verbal-auxiliary half-lines in the third word order also demonstrate an association with metrical types, but to discuss the relation it will be necessary to distinguish between mono- and disyllabic auxiliaries. ${ }^{32}$ If the auxiliary is monosyllabic the half-line is type $3 \mathrm{~B}$ or $3 \mathrm{~B}^{*}$; disyllabic auxiliaries are divided between half-lines of types $2 \mathrm{~A}$ and $2 \mathrm{C}$. Table 2 shows the relation between word order and metrical types of verbal-auxiliary half-lines. The best way to analyse the results is to consider mono- and disyllabic auxiliaries separately. When

${ }^{30}$ Krämer emended to gepwened (xx.102b); if the reading in MS C is left unemended, gepawened undergoes resolution, so for metrical purposes the two forms are almost identical. Assmann and Krämer also emended weorda $($ from C) to weorded for the sake of agreement in number. ${ }^{31}$ Type IA appears nowhere else; type IA* occurs twice in the third word order: 'secgan geherde' (IX.1 I a) and 'dioton ongunnon' (xxvi.8ob).

32 So far in this study auxiliaries like ne sceal and ongind have been treated as monosyllabic and ne sceoldon and ongunnon as disyllabic; moreover, auxiliaries like bafad have been considered monosyllabic whether or not they undergo resolution. When these verbs are analysed metrically, however, the proclitics and prefixes must be taken into account, and verbs like bafad not subject to resolution must be treated as disyllabic. The differences arising from the two ways of treating the additional syllables are too slight to affect my conclusions, but the occasional differences should be noted. 


\section{Daniel Donogbue}

auxiliaries in the third word order are monosyllabic the results are not surprising. The verbal has three syllables, one of which is an unstressed prefix, for instance 'gestigan wile' (xxIx.I 2b). ${ }^{33}$ When the auxiliary is disyllabic the results are more difficult to explain. One would expect greater diversity in metrical types because, theoretically, the auxiliary could be preceded by a negative proclitic or could have an unstressed prefix. (Two of the seven monosyllabic auxiliaries have negative proclitics.) The versifier carefully limited the number of syllables in these half-lines to conform to only two metrical patterns. ${ }^{34}$ The typical auxiliary does not have a negative proclitic or an unstressed prefix, so it is metrically disyllabic. When the auxiliary comes first in the half-line the verbal usually has three syllables, one of which is an unstressed prefix, for instance 'wille gepencan' (xIII.27b). When the auxiliary comes second (for examples, see below), the verbal has an unstressed prefix only with type $2 \mathrm{C}$, since anacrusis is not allowed with type $2 \mathrm{~A}$.

For some passages it is possible to trace how the versifier consistently changed a wide variety of verbal-and-auxiliary pairs from the prose into halflines of verse that conform to specific metrical types. The following columns give some selected auxiliaries and verbals from the prose (on the left) and the corresponding half-line of verse:

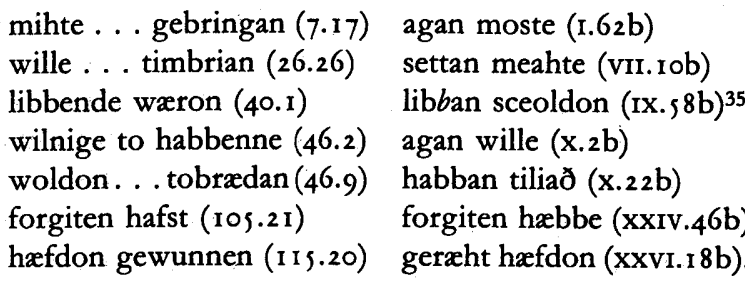

33 The half-lines with monosyllabic auxiliaries are 'tosceaden wyrð' (v.18a), 'wile onlatan' (xI.75b, with resolution of wile), 'gesecgan ne mæg' (xIx.4ob), 'mæg aweorpan' (xxiII.6b), 'ymbebæted hæfo' (xxIv.37b, the medial $e$ in ymbebated to be ignored in scansion), 'gebidan ne magon' (XxvIr. 7 a, with resolution of magon) and 'gestigan wile' (XXIX. I $2 \mathrm{~b}$, with resolution of wile).

34 Some passages show changes from the prose that are so extensive that they can be most plausibly explained as the result of efforts to give them the preferred metre. See, e.g., virr.2 I b-23a (prose 33.29) and xI.69b-70 (49.24), where the versifier removed the negative proclitic and placed it in an introductory clause (not found in the prose) in order to preserve the negative sense. Another verse passage, vir.4a-6a (prose 26.24), shows how the poet added a prefix to the verbal, transferred the negative proclitic to an introductory clause and changed the tense of the auxiliary to give the half-line the metrical type $\mathrm{IA}^{*}$ : 'meahte asettan' (vII. sb). Cf. the half-line 'settan meahte', five lines below. Each half-line's metrical type follows a pattern determined by the relative positions of the auxiliary and verbal. If a disyllabic auxiliary is first, the half-line is given metrical type $1 \Lambda^{*}$; if it is second, metrical type $2 \mathrm{~A}$. In all of these examples the prose influence on the word order is negligible.

35 Krapp and Sedgefield followed MS C in the spelling liban (IX. $58 \mathrm{~b}$ ), but for the sake of metre I follow Krämer and Assmann in correcting it to libban.
Word order and poetic style: 'The Metres of Boetbius'

In the prose the number of syllables varies from one to three; the auxiliary is found before and after the verbal. In the verse, however, the words are all metrically disyllabic, and the auxiliary is always the second word. ${ }^{36}$ As a result of the versifier's changes the dissimilar auxiliaries and verbals in the prose are transformed into half-lines of the third word order $\left(\mathrm{V}^{\mathbf{v}}\right)$ and of metrical types $2 \mathrm{~A}$ and $2 \mathrm{C}$.

Half-lines composed of a subject pronoun + verbal + auxiliary are a special sub-category of verbal-auxiliary half-lines. It will be recalled that of the nine exceptions to the usual word order in principal clauses, five are verbalauxiliary half-lines and four are in half-lines with a subject pronoun followed by a verbal and auxiliary. The latter four are 'He gongan sceal' (Iv. I $7 \mathrm{~b}$ ), 'ðu forlætan scealt' (v.26b), 'pu gehicgan meaht' (xIX. I 7 b) and 'Ic gereccan mæg' $(x x v .37 b)$. One may include with these the following half-lines from clauses of doubtful status: 'se toglidan ne pearf' (vrr. 34b) and 'se gehaten wæs' (x.46b). ${ }^{37}$ The resemblance of these six examples to certain verbal-auxiliary half-lines is readily apparent. The differences between them and a half-line such as 'gestigan wile' (XXIX. I 2b) is simply an unstressed particle. Indeed, it can be argued that in some half-lines, such as IV.I7b and V.26b (above), the pronoun is grammatically superfluous. In the former instance the pronoun is repeated from the immediately preceding clause, and the ending of the auxiliary sceal limits the possible subjects to the first or third person singular; in the latter the ending of scealt indicates that $\partial u$ from line 24 must be the subject. However, the initial pronoun may be necessary for another reason: if it were removed, the clause would begin with a verbal - a word order the versifier scrupulously avoided. 38

In many instances a comparison with the prose reveals that the versifier altered the prose beyond the requirements for syntax and alliteration in order to give the verbal-auxiliary half-line a particular metrical type. Here metre seems to have acted like a Procrustean bed, forcing the versifier to decrease or

36 The two trisyllabic words, tiliad and forgiten, undergo resolution.

37 Krämer inexplicably placed se in the previous half-line, yet punctuated so that it remained in the clause with 'gehaten wæs' (x.46b). Half-lines with similar constructions but with a first word which is not a subject pronoun include 'ac gepweorod sint' (xx.72a), ' $\partial x 2$ forweorðan scylen' (xxI.34b) and 'swa bereafod sie' (xxIr. $\mathrm{ob}$ ). In other similar half-lines, 'Da biod gehyrste' (xxv.8b) and 'Para is gehaten' (xxvII.25b), the alliteration falls on the initial particle, so that the following verb is unstressed. I consider these five to be exceptions to the variations of verbal-auxiliary half-lines discussed here.

$38 \mathrm{~S}$. O. Andrew took exception 'to half-lines in Beowulf such as 'Ic gefremman sceal' on the grounds that a conjunction must have been dropped from them. Otherwise, according to his strict application of the principles of syntax, there is no way to account for the conjunctive order (S [O. . .] Vv) (Syntax and Style, \$70). Bliss noted a 'slight preference' for considering such half-lines subordinate but he allowed that they may also be principal ('Auxiliary and Verbal', p. 178). 


\section{Daniel Donoghue}

increase the number of syllables for each possible verbal and auxiliary. When a verbal-auxiliary half-line occurred in a principal clause the usual restriction of word order ( $\mathrm{vV}$ or $\mathbf{v} \mathrm{V})$ was waived. It seems that as long as a verbal and auxiliary fitted neatly into a metrically acceptable half-line, the poet was free to use it without regard to the grammatical function of the clause. In these cases a preference for metrical patterns superseded the usual syntactic rules and accounts for the word order of the nine exceptional half-lines in principal clauses.

$$
\text { 'Se pe' clauses }
$$

Two of the six unstressed auxiliaries which are exceptions to the expected word order of dependent clauses may have been the result of prose influence (mag (X.1 2a) and bid (xxIr. 37a) from the prose (46.5 and 95.13). Another three exceptions do not reveal any prose influence but have something else in common: they appear in clauses beginning with se pe. The following discussion will examine these clauses in more detail. This study so far has assumed that the initial word of a clause is the only objective evidence determining whether a clause is dependent or principal. In passages beginning with se pe, however, the position and stress of the auxiliary show that the distinction between types of clauses has become obscured. This problem does not arise in Beowulf since the grammatical function of its clauses has little effect on the position and stress of the auxiliary.

In their Guide to Old English Bruce Mitchell and Fred Robinson distinguished two uses of se pe. ${ }^{39} \mathrm{In}$ the first, the words function together as a simple relative pronoun. It can be called the sepe relative. In the second use the se and the $p e$ belong to two separate clauses, and the demonstrative is in the case of its antecedent in the principal clause. Mitchell and Robinson gave the following example from Beowulf:

$$
\begin{aligned}
& \text { syððan hie gefricgeað frean userne } \\
& \text { ealdorleasne, pone ðe ær geheold } \\
& \text { wio hettendum hord ond rice. (3002-4b) }
\end{aligned}
$$

They commented: 'Formally, pone belongs to the principal clause and we can therefore say that the relative . . . is $\partial e$. ' They continued, 'there is already an antecedent and the demonstrative is therefore superfluous'. ${ }^{40}$ In cases like this,

39 A Guide to Old English Revised with Texts and Glossary (Toronto, 1982) §162.4. See also the

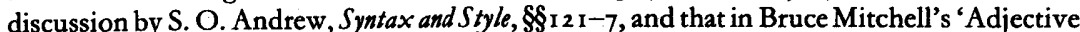
Clauses in Old English Poetry', Anglia 8 1 (1963), 298-322. Mitchell's Old English Syntax has appeared since the first draft of this paper, and his sections on se pe clauses $(\$ 2153-362)$ should be consulted, esp. $\$ 2159$ and 2204, for observations that differ from those presented here.

40 G Guide, \$163.1.
Word order and poetic style: 'The Metres of Boethius'

when the demonstrative has the case of its antecedent in the principal clause, it is useful to speak of the se pe relative. The sepe relative, on the other hand, belongs only to the dependent clause.

One passage in the Metres provides a good example of a se pe relative: ' $\mathrm{Pa}$ ðe leon wxron ongunnon laðlice / yrrenga ryn' (xxvi.83-4a). There are two clauses: ' $\mathrm{Pa}$... . ongunnon' etc. and 'ðe leon wron'. The relation to the corresponding prose passage (116.16) is very loose, so it seems that the verse construction owed more to the conventions of poetry than to the influence of the prose model. Formally, $P a$ is the initial word of the principal clause, but it appears immediately before the initial word of the relative clause. The separation of $P a$ from the clause to which it belongs causes few grammatical difficulties, but as a displaced particle it introduces a complication in the relation between metre and the starting point of a clause. Kuhn's First Law speaks of particles grouped before or immediately after the first stressed word of the clause. In the example just given both $\mathrm{Pa}$ and ongunnon are unstressed particles before the first stressed word of their clause, but they are not grouped together; a relative clause separates them. Similarly in the earlier example from Beowulf, pone is formally part of the principal clause, but it is placed with $\partial e$ in the dip at the beginning of the relative clause. It may be necessary, therefore, to distinguish two starting points for clauses in which the demonstrative of a se pe relative is the proleptic subject. The demonstrative is the grammatical starting point of the clause; the dip at the beginning of the half-line where the clause resumes can be called the 'metrical' starting point of the clause. The demonstrative is not always superfluous as it is in the Beowulf passage; in the example from the Metres, $p a$ is the only subject-expressed or unexpressed-of ongunnon.

It will be illuminating to examine two passages of verse which employ se pe relatives and which correspond to two prose passages beginning with swa bwa swa:

$$
\begin{aligned}
& \text { Se pe wille wyrcan wæstmbære lond, } \\
& \text { atio of ðæm æcere xrest sona } \\
& \text { fearn and pornas and fyrsas swa same (XII.I-3b); }
\end{aligned}
$$

Swa hwa swa wille sawan westmbære land, atio ærest of ða pornas and pa fyrsas and pæt fearn ... (5x.28)

$$
\begin{aligned}
& \text { Se pe æfter rihte mid gerece wille } \\
& \text { inweardlice æfter spyrian } \\
& \text { swa deoplice, pæt hit todrifan ne mæg } \\
& \text { monna ænig ne amerran huru } \\
& \text { ænig eorðlic ðincg, he ærest sceal } \\
& \text { secan on him selfum (xxIr. I-6a); }
\end{aligned}
$$$$
\text { I } 81
$$ 


\section{Daniel Donoghue}

Swa hwa swa wille dioplice spirigan mid inneweardan mode $x$ fter ryhte, and nylle pær hine ænig mon oððe ænig ping mage amerran, onginne ponne secan oninnan him selfum ... (94.27)

In each verse passage the relative $p e$ begins an indefinite adjective clause, and se pe serves as an equivalent to the prose phrase swa bwa swa. In the first example the demonstrative is the only word which can serve as the subject of the principal clause. In the second instance the subject is repeated because the demonstrative is far removed from the rest of the principal clause, which continues in the $b$ verse of line 5 . In both of these verse passages, it must be remembered, the demonstrative se falls in the metrical dip at the beginning of the relative clause, even though it is the grammatical subject of the principal clause.

There are two passages in the Metres which begin with a se pe relative and which correspond to prose passages with se $p e$ :

$$
\text { Se pe wille anwald agon, ठonne sceal he xrest tilian (xvi.I), }
$$

$\mathrm{Se}^{41}$ pe wille fullice anweald agan, he sceal tiligan ærest . . (67.26);

$$
\begin{aligned}
& \begin{array}{l}
\text { Se ðe ðonne nu sie } \\
\text { mid pisses mæran }
\end{array} \begin{array}{l}
\text { nearwe gehefted } \\
\text { middangeardes }
\end{array} \\
& \begin{array}{l}
\text { unnyttre lufe, sece him eft hræðe } \\
\text { fulne friodom } \\
\text { (xxI.5-8a), }
\end{array}
\end{aligned}
$$

and se ðe nu gehæft sie mid pære unnyttan lufe pisses middaneardes sece him freodom ... (89.6)

One may add to these another passage which begins in both the prose and verse 'Ac se pe':

$$
\begin{aligned}
& \text { Ac se ðe pa ecan agan wille } \\
& \text { soðan gesælða, he sceal swiðe flion } \\
& \text { Xisse worulde wlite (vir.29-3 ra), }
\end{aligned}
$$

Ac se pe wille habban pa ecan gesælða he sceal fleon ðone frecnan wlite pises middaneardes ... (27.4).

Unlike the ' $\mathrm{Pa}$ pe leon' passage, these last three verse passages are almost direct transcriptions from the prose. The particle ( $A c$ or se) which is the initial word of one clause is placed with pe in the dip before the first stressed word of the relative clause. In two of the verse passages there are pleonastic subjects (VII. $3 \mathrm{Ob}$ and XVI. I b), which are found also in the corresponding prose passages $(27.4$ and 67.26). It may be argued that some or all of the se pe relatives in these

$$
41 \text { The reading of MS B is 'ðe pe wille'. }
$$

Word order and poetic style: 'The Metres of Boethius'

examples (and elsewhere) are in fact sepe relatives used as indefinite pronouns. A sepe relative, furthermore, would eliminate the apparent discrepancy between the grammatical and 'metrical' starting points of the clauses. While one must make allowance for the possibility of this argument, it is not convincing. In prose a sepe relative is often used when ambiguities of case exist or when the antecedent of $p e$ lacks a demonstrative. In the passages just quoted from the Metres, however, there is no antecedent and no ambiguity of case.

The six verse passages introduced by se pe relatives correspond to a variety of prose constructions. The verse beginning ' $\mathrm{Pa}$ de leon' does not seem to depend on the prose model very much; the two prose passages beginning swa bwa swa are rendered in verse with se pe clauses; and the three se pe passages in the prose are reproduced in the verse with only slight alterations. Despite the diversity in the prose, there is every reason to believe that the consistency found in the construction of the verse passages is matched by uniformity of meaning. All the se pe relatives in the verse translate perfectly well as 'he who' or 'those who'.

Since different patterns of word order and stress can distinguish principal and dependent clauses, the questions arise: 'Does the separation of se from the clause to which it formally belongs affect the position and stress of the auxiliary? Does the inclusion of the demonstrative in the initial dip of the relative clause affect the auxiliary of the relative clause?' In the six $p e$ clauses so far considered there are five auxiliary-and-verbal pairs. In four of them the auxiliary precedes the verbal, and in two of these four the auxiliary is unstressed. In other words, two of the five relative clauses follow a pattern usually reserved for principal clauses. Two more follow a word order common to both kinds of clauses. The fifth auxiliary is in the relative clause of the passage introduced by 'Ac se ðe', and its auxiliary is stressed and after the verbal, a word order characteristic of dependent clauses. The dependent clause formally begun by $A c$ has an unstressed auxiliary; it behaves as if be were the first word and the clause were principal.

These examples demonstrate that the separation of se from the clause to which it formally belongs induces deviations from the usual patterns of word order. Clauses introduced by $p e$ should have stressed auxiliaries, yet in xIr. Ia and XVI.ra they are unstressed. Similarly, clauses introduced by coordinating conjunctions should have stressed auxiliaries, yet sceal in vir. $30 \mathrm{~b}$ is unstressed. It seems that the first word in the dip at the beginning of the clause determines the stress and position of the auxiliary even if that word is not the grammatical starting point of the clause. Thus, when a se $p e$ relative begins a passage, the auxiliary in the relative clause is placed before the verbal and may not bear a stress. Here one may note another objection to the argument that these clauses 


\section{Daniel Donoghue}

are introduced by sepe relatives. The pattern shown by sepe relative clauses would consistently follow the pattern for dependent clauses; that is, the auxiliary would always be stressed.

The separation of the demonstrative from the rest of the principal clause and therefore from the first stressed word of the clause seems to be contrary to Kuhn's First Law. However, it may be more correct to say that se pe clauses present a complication that Kuhn did not envisage. S. O. Andrew argued that in Beowulf initial demonstratives of passages like this should be eliminated. ${ }^{42}$ His argument was based on the observation of false concord between the demonstrative and its antecedent. While his solution to the difficulty seems extreme (it is unlikely that Old English poets strove for the precision of concord expected by Andrew), it is illuminating to note that these passages are exceptional for reasons other than metre and word order.

\section{Relation of the prose to the verse}

Before I take up the clauses of doubtful status, it will be helpful to examine in more detail the extent of the prose influence on the verse. The relation between the two can be divided into three categories: the verse either (I) repeats or (2) reverses the position of the auxiliary with respect to the verbal in the prose, or (3) there is no corresponding prose passage with an auxiliary and verbal. (In the case of (3) the verse may have expanded a simple finite verb or the verse passage may be an independent addition by the poet.) For principal clauses there can be only two possible relations with the prose, because in both prose and verse the auxiliary usually precedes the verbal. If the position of an auxiliary in the prose is changed so that it follows the verbal in the verse, then the word order becomes characteristic of a dependent clause; that is, the word order in a principal clause is reversed only when there is a corresponding change of the clause from principal to dependent. Therefore principal clauses in the verse either (I) repeat the word order of the prose or (3) the auxiliary and verbal are not found in the prose. 43

For principal clauses the relationships with the prose are summarized in table 3. When the verse repeats the word order of the prose the results are not surprising: the auxiliary precedes the verbal in all twenty-seven cases. The pattern changes, however, when the auxiliary and verbal are found only in the

42 Syntax and Style, $\$ 12 \mathrm{I}-7$. Pace Andrew, false concord is not a compelling reason to suspect scribal corruption. Indeed, the consistency with which false concord occurs - particularly in what he calls exepegetical para pe passages - suggests that such usage was acceptable to the poet.

43 There are two exceptions, 'weorðan sceolden' (xxIx.86b) and 'weorðan sceoldon' (xxIx.88a), which reverse the word order of the prose to the third word order $\left(\mathrm{V}^{\prime}\right)$ in order to form verbal-auxiliary half-lines. Since a second, dependent, verbal is added to each clause, however, they may be considered 'newly introduced' in a sense.
Word order and poetic style: 'The Metres of Boethius'

TABLE 3

\begin{tabular}{|c|c|c|}
\hline \multirow[t]{2}{*}{ Word order } & \multicolumn{2}{|c|}{ Total } \\
\hline & $\begin{array}{l}\text { (1) Word order unchanged } \\
\text { from that of prose }\end{array}$ & $\begin{array}{l}\text { (3) Auxiliary and verbal } \\
\text { not in prose }\end{array}$ \\
\hline $\mathrm{vV}$ & เ 8 & II \\
\hline$\dot{v}^{\prime} \mathrm{V}$ & 9 & 8 \\
\hline$V_{v}^{\prime}$ & 0 & 9 \\
\hline Total & 27 & 28 \\
\hline
\end{tabular}

verse; here there is an almost equal distribution among the three word orders. What is most unusual is that all nine exceptions ( $V$ v') to the expected pattern for principal clauses were employed by the poet without any apparent influence from the prose. He deliberately chose to change the distribution of word orders from the prose. The nearly equal distribution in (3) suggests that variety in verse word order was not only permissible but also expected.

Table 4 summarizes the three ways in which dependent verse clauses depend on the prose model. The first column shows that the prose exerted a limited influence when the word order of dependent clauses differs from the expected pattern; that is, when the auxiliary is unstressed. All six clauses with an unstressed auxiliary duplicate the word order of the prose. A relatively small proportion (six out of thirty-four) of verbals precedes the auxiliary when the word order follows the prose. The second and third columns accord with the expected word order; the auxiliary is stressed in all fifty-four instances. The versifier's consistent preference for stressed auxiliaries in the absence of prose influence reveals that he was observing a poetic convention. In these two columns the third word order is more common than the second. The high proportion of auxiliaries following the verbal is not unexpected, but it makes the small number of the third word order in the first column somewhat puzzling.

TABLE 4

\begin{tabular}{cccc}
\hline \hline Word order & \multicolumn{4}{c}{ Total } \\
\cline { 2 - 4 } & $\begin{array}{c}\text { (1) Word order unchanged } \\
\text { from that of prose }\end{array}$ & $\begin{array}{c}\text { (2) Word order cbanged } \\
\text { from that of prose }\end{array}$ & $\begin{array}{c}\text { (3) Auxiliary and verbal } \\
\text { not in prose }\end{array}$ \\
\hline vV & 6 & 0 & 0 \\
v́V & 22 & 6 & 18 \\
V́́ & 6 & 9 & 21 \\
Total & 34 & Is & 39 \\
\hline \hline
\end{tabular}

I 85 


\section{Daniel Donoghue}

This comparison between the prose and the verse reveals some of the differences between the rules of prose syntax and the conventions which the poet seems to have observed. In principal verse clauses all auxiliaries taken from the prose precede the verbal and most of the auxiliaries are unstressed. The auxiliaries found only in the verse, however, follow a more varied pattern. They are almost equally distributed among the three word orders. The difference between the two columns of totals is not necessarily evidence that verse syntax is always so varied when it is free from prose influence. The versifier of the Metres may have felt that a certain amount of variation was desirable and found it easier to invent passages with a particular word order than to change the position of the auxiliary found in the prose. Therefore the proportion of deviations in newly introduced auxiliaries may be higher than the usual practice of the poet. The greater variety seems to have been due to his unrestricted use of verbal-auxiliary half-lines in the third word order. In any case some degree of variation in the position of auxiliaries in principal clauses is more characteristic of verse than of prose. In dependent clauses, however, the poet did not introduce any variation from the expected pattern. All newly introduced auxiliaries and all auxiliaries with a changed position are stressed. They are unstressed only when they follow the word order of the prose passages from which they were derived. The poet rarely took a verbal and auxiliary in the third word order from the prose; he seems to have preferred to compose new passages in which the auxiliary follows the verbal or to reverse their word order from the prose.

\section{Clauses of doubtful status}

The groundwork has now been laid for study of the clauses of doubtful status. The grammatical function of these clauses is uncertain because of the uncertain function of the initial particle. For example, an initial $p a$ is sometimes a subordinating conjunction and sometimes an adverb. If it is a conjunction, the clause is dependent; if an adverb, the clause is principal. When an ambiguous particle like $p a$ introduces a prose clause, however, the word order often indicates the function of the clause: if the initial particle is followed by the demonstrative order (vSO) the clause is principal; if it is followed by the conjunctive order (SO . .v) the clause is dependent. By contrast, in verse there is no way of distinguishing between the conjunctive and the demonstrative orders. Campbell called this lack of distinction the 'major weakness' of Old English verse. He explained, 'In verse, subordinate and demonstrative order are the same. The clause is introduced by a conjunction or adverb, and these are of the same effect on word-order. They open the clause with a dip, and all unaccented adverbs and pronouns, and the verb if it be unaccented, are
Word order and poetic style: 'The Metres of Boetbius'

drawn into that dip' ${ }^{44}$ The results of this study allow one to make the kind of distinction in the Metres that Campbell found lacking in Old English verse in general. The previous pages have demonstrated that unstressed auxiliaries are usual in principal clauses; conversely, auxiliaries in dependent clauses are almost never unstressed. On the assumption that these observations are applicable to clauses of doubtful status, it follows that when the auxiliary is drawn into the dip before the first stressed word, the clause is principal. Since auxiliaries which follow the verbal are usually found in dependent clauses, it is likely that the same word order in a 'doubtful' clause is a good indication that the clause is dependent. Therefore one could tentatively assign all the auxiliaries in the first word order to principal clauses and all in the third word order to dependent clauses. Thus some of the uncertainty surrounding these clauses is dispelled, but not all. Such a procedure makes no allowance for exceptions, and the distribution shows that the first and third word orders account for less than half the auxiliaries in clauses of doubtful status: $\mathrm{vV} 28, \mathrm{v}^{\mathrm{V}}$ 80 and V'́ 39. The majority of clauses - those in the second word order would still be doubtful; both the initial particle and the stressed auxiliary reveal nothing about the grammatical function of the clause.

One way to include all clauses of doubtful status in an analysis is to consider them according to the punctuation found in Krapp's edition. So far in this study the punctuation almost always conforms to what one would expect in clauses unambiguously dependent or principal. If peab begins a clause it is punctuated as dependent; if be begins one it is punctuated as principal. For the sake of discussion I will assume that clauses of doubtful status are also punctuated correctly most of the time. Clauses punctuated as principal can be distinguished from those punctuated as dependent and the two groups analysed separately. Only a few passages are punctuated in such a way that the nature of one or more clauses is uncertain. In most cases an examination of the prose helps to clear up any doubt. 45

The distribution of clauses punctuated as principal is $\mathrm{vV} 23, \mathrm{v}^{\prime} \mathrm{V} I 8$ and $\mathrm{V}^{\prime} 2$.

44 'Verse Influences in Old English Prose', Philological Essays . . . in Honour of Herbert Dean Meritt, ed. James L. Rosier (The Hague, 1970), pp. 93-8, at 95. Campbell used the term 'subordinate' for the word order I call 'conjunctive'.

45 In one case the prose offers little help: $x .35 a-37 b$, prose $46.17-18$. Judging from the sense of the passage as a whole, $I$ interpret the first clause as principal and the second as dependent. While the position and stress of the auxiliary in many cases show the grammatical function of the clause, a clause of doubtful status with an auxiliary in the second word order ( principal, dependent or an apo koinou clause. In considering clauses like this it may be wise to fall back on the suggestions made by Bruce Mitchell in 'The Dangers of Disguise: Old English 'Texts in Modern Punctuation', RES n.s. 3I (1980), 385-4I3, where he argued against holding a strict distinction in some cases between principal and dependent clauses. 


\section{Daniel Donoghue}

This distribution is proportional to the distribution for clauses unambiguously principal; 46 the position of the auxiliary before the verbal rather than stress distinguishes principal clauses. The two exceptions include a verbal-auxiliary half-line ('gebidan ne magon' (xxvir.7a)) and a half-line consisting of a subject pronoun + verbal + auxiliary ('se toglidan ne pearf' (vIr.34b)). These conform exactly to the pattern of the nine exceptions for clauses unambiguously principal. 47 Even the relation between 'doubtful' clauses and the prose closely resembles the relation observed for clauses unambiguously principal. When the word order is unchanged from the prose (r) the distribution is $\mathrm{vV}$ I $7, \mathrm{~V}^{\mathrm{V}} \mathrm{I} 0$ and $\mathrm{V}$ ' 0 . When the auxiliary and verbal are not found in the prose (3) the distribution is $\mathrm{vV} 6, \mathrm{vV}^{\prime} 8$ and $\mathrm{Vv}^{\prime}$. The similarities with clauses unambiguously principal are obvious. ${ }^{48}$ When the poet followed the prose word order, the auxiliary always precedes the verbal and remains unstressed in half the instances. In passages not derived from the prose, however, the poet introduced variation in the word order which is uncharacteristic of prose.

Clauses punctuated as dependent yield quite different results. Their distribution is $\mathrm{vV} \mathrm{5,} \mathrm{vV}_{2}$ and V' 37 . Here again the similarity with the corresponding unambiguous clauses is striking. 49 The auxiliary is unstressed only five times out of 104. ${ }^{50}$ The similarity is carried over to the three ways in which clauses punctuated as dependent are related to the prose model. The following distributions compare closely with the corresponding distributions of clauses unambiguously dependent: ${ }^{51}$ ( $\mathrm{I}$ ) word order unchanged from that of prose, $\mathrm{vV}$

46. See above, p. 175 .

47 See above, n. 22, and the discussion of verbal-auxiliary half-lines, pp. 172-82.

48 See above, table $3 . \quad 49$ See above, p. 176.

50 The five unstressed auxiliaries are sceal (II.2b), is (xvi. I b), was (xxvI.96a), hafo (xxvIr. 26b) and magon (xxx.18a). The corresponding prose clauses are 8.6, 67.32, 116.25, 126.9 and 141.19. Not every editor has agreed that each of the five verse clauses is dependent; three are punctuated differently in some editions: Assmann and Sedgefield punctuated II. $2 \mathrm{~b}-4 \mathrm{a}$ as principal, Krämer and Sedgefield punctuated xxvi.96-7a as principal and Assmann and Krämer punctuated xxvir. $26 \mathrm{~b}-27$ as principal. Sedgefield punctuated three of the five corresponding prose clauses as principal, including the two corresponding to the verse clauses he considered principal (8.6 and 116.25 for the verse II. $2 \mathrm{~b}-4 \mathrm{a}$ and xxvI.96-7a). The third principal prose passage is 141.19 (for $\mathrm{XxX} .18$, which all editors have considered dependent), but it has a loose syntactic relation to the verse: one prose clause is expanded into two verse clauses. The results of this study favour the alternative punctuation for the three verse clauses mentioned above. Furthermore, the respective passages do not suffer in meaning or syntactic smoothness when these clauses are construed as principal. The other two clauses (xvi. I s b and xxx. 18 ) should remain dependent, because the passages where they appear would suffer from a change in punctuation. Consequently, simple repunctuation in accord with other editors' choices can reduce the total number of exceptions to two out of I04, a proportion that is even more one-sided than for clauses unambiguously dependent. 51 See above, table 4.
Word order and poetic style: 'The Metres of Boetbius'

\begin{tabular}{ccc}
\multicolumn{3}{c}{ TABLE } \\
\hline \hline Word order & \multicolumn{2}{c}{ Type of clause } \\
\cline { 2 - 3 } & Principal & Dependent \\
\hline VV & 51 & I I \\
v́V & 36 & 108 \\
V'́ & II & 73 \\
Total & 98 & 192 \\
\hline
\end{tabular}

3,,$\dot{V} 30$ and $\mathrm{V} \dot{v} 6 ;$; (2) word order changed from that of prose, $\mathrm{vV} o, \dot{v} \mathrm{~V} 8$ and V'́ I I; and (3) auxiliary and verbal not derived from prose, $\mathrm{vV} 2$, v́V 24 and $\mathrm{V} \dot{v}$ 20. It seems that when the poet preserved the word order found in the prose, he preferred clauses in which the auxiliary precedes the verbal. However, when he departed from the prose, he used the second and third word orders with equal regularity (thirty-two of the former and thirty-one of the latter).

The results of these comparisons lend support to the supposition that Krapp's punctuation is correct most of the time. Deviations from the expected pattern are proportionally no greater than in clauses unambiguously principal or dependent. Thus with some confidence one can combine, in table 5, the distributions for the clauses of doubtful status with those for their unambiguous counterparts. ${ }^{52}$

\section{AUXILIARIES AND POETIC STYLE}

Comparison of the verse with the prose ${ }^{53}$ has shown that the poet frequently introduced auxiliaries and verbals which are not found in the prose. This comparison does not necessarily demonstrate, however, that auxiliaries and verbals appear in the verse more often than in the prose. It is possible, for instance, that the poet eliminated as many auxiliaries and verbals from the prose as he introduced into the verse, so that the relative proportions in the prose and verse are about equal. An examination of a representative Metre with the prose model, however, shows that the proportions are not the same. In Metre $x$ there are fifty-six verbs, seventeen of which are auxiliaries. In the corresponding prose passage there are fifty-two verbs, only ten of which are auxiliaries. All the verbals in the prose are reproduced in the verse (at least in synonymous form): since auxiliaries generally carry less meaning than verbals

52 Note that the fifty-three initial auxiliaries are not included, but when they are, the fifteen asyndetic coordinate clauses significantly increase the number of instances of the first word $\operatorname{order}(\mathrm{vV})$ in dependent clauses. Revised to include initial auxiliaries, the distributions are for principal clauses vV 88, v́V 37 and V'́ 1 i and for dependent clauses vV 26, v́V 108 and V'́ 73. 53 See above, tables 3 and 4 and pp. 186-8. 


\section{Daniel Donoghue}

they can be replaced without a significant change in the meaning of the passage. The versifier never lost an opportunity to preserve an auxiliary-verbal combination from the prose, and he increased the number of them by adding seven not in the prose. The number of all verbs increases slightly; the number of auxiliaries increases by $70 \%$. It is likely, then, that the versifier considered auxiliaries and verbals more useful in verse than in prose. If, for instance, he expanded a simple finite verb from the prose into an auxiliary and verbal, the verse gained a stressed word (the verbal) which could be used in alliteration. The two words offered the versifier a variety of possibilities not available with a simple finite verb.

One more observation about the verbs in Metre $\mathrm{x}$ remains to be made. It has been demonstrated that the position and stress of auxiliaries in the Metres depends to a great extent on the grammatical function of the clause. It is an attractive possibility that all finite verbs in the Metres follow the same patterns of stress as the auxiliaries. (A full discussion of word order would be futile, since in too many clauses there are not enough elements - subject or object - to determine the position of the verb in the word order.) In Metre $x$ thirty-nine finite verbs are not auxiliaries; fourteen are unstressed. All but two of the unstressed verbs are in clauses punctuated as principal. The other two clauses are, curiously enough, of doubtful status. ${ }^{54}$ Repunctuation can make the status of these clauses accord with the majority containing an unstressed auxiliary. One clause which Krapp punctuated as principal should be repunctuated as dependent: 'Ac hit is wyrse nu' (x. $57 \mathrm{~b}$ ). The verb is unstressed. Thus, out of the thirty-nine 'non-auxiliary' verbs in Metre $\mathrm{x}$, is in this half-line is the only certain instance of an unstressed verb in a dependent clause.

Seventeen of the fifty-six finite verbs in Metre $\mathrm{x}$ are unstressed, and only two unstressed verbs occur in clauses unambiguously dependent. It seems reasonable to conclude that the association between the stress of the auxiliary and the grammatical function of the clause applies to all finite verbs in this Metre. The conclusion can be tentatively applied to all the Metres: unstressed verbs are usually found in principal clauses and, conversely, dependent clauses usually contain stressed verbs.

Throughout this study Beowulf has been used as a standard of comparison for the Metres, yet the comparison reveals some significant differences in word order which cannot be explained simply as the inevitable result of judging a weak poem by the standards of a great one, or a later poem by an earlier one, or a philosophical poem by a heroic narrative. Moreover, the fact that the Metres were composed directly from a prose model cannot account for its distinctive word order, nor is it a compelling reason to consider the Metres apart from the

$$
54 \text { At X.50a and x. } 5 \mathrm{Ib} \text {. }
$$

Word order and poetic style: 'The Metres of Boethius'

main stream of poetic tradition. Despite the versifier's close adherence to the prose model, relatively few passages of verse betray their prose origins. The versifier was competent enough to compose his verse without making it unduly prosaic. What the Metres poet did imperfectly another poet may have done better, but all Old English poets, good and bad alike, held in common some elementary techniques of their craft. Therefore one is justified in comparing certain, limited aspects - such as the fundamentals of syntax - of any Old English poem with another.

Despite the Beowulf poet's superior ability, one would expect that the basic patterns of word order discernible in his poem would resemble those of other poems. It comes as a surprise, then, to discover that the principles of word order for auxiliaries in the Metres are entirely different from the tendencies in Beowulf, where, Bliss observed, 'the position of the auxiliary is dictated, not by the grammatical function of the clause, but by the presence or absence of an introductory particle or (if the auxiliary is monosyllabic) by the number of introductory particles'. ${ }^{55}$ Clearly the Metres poet was adhering to a separate poetic convention, which is in itself neither superior nor inferior to the conventions observed by the Beowulf poet. The Metres show other departures from the poetic technique of Beowulf, which may be explained on the basis of a separate poetic convention. In Beowulf only one auxiliary alliterates in preference to a noun, in breach of Sievers's Rule of Precedence. In the Metres, twelve auxiliaries violate Sievers's Rule, and the count does not include other finite verbs. In the Metres forms of the verb beon used as an auxiliary are often stressed; in Beowulf they are only rarely. In the Metres verbal-auxiliary half-lines are restricted to a handful of metrical types; the permissible range is different in Beowulf. ${ }^{56}$ Finally, the Metres poet seems to have been less reluctant to violate Kuhn's First Law, although this tendency may reveal nothing more than the Beowulf poet's superior ability at verse-making.

Alistair Campbell observed that the Old English epic style, exemplified in Beowulf, developed from earlier Germanic lays, two of which survive in the Old English Finnesburg and the Old High German Hildebrand. ${ }^{57}$ While Campbell directed his comments to the development of the epic style from the earlier lays, it is likely (though he did not say so) that poetry composed in the style of lays continued past the birth of the epic style. In general the epic style

55 'Auxiliary and Verbal', p. 178.

56 Cf. the Appendix, ibid. pp. $180-2$, where Bliss pointed out entirely different influences in Beowulf that may account for the presence of the prefix ge- on the past participle. Moreover, there are eleven half-lines, such as 'habban ne mihte' and 'Jurhfon ne mihte' (Beo. $462 \mathrm{~b}$ and I $504 \mathrm{~b}$ ), which conform to metrical patterns avoided in the Metres.

57 'The Old English Epic Style', English and Medieval Studies presented to J. R. R. Tolkien on the occasion of his Seventieth Birthday, ed. Norman Davis and C. L. Wrenn (London, 1962), pp. $13-26$. 
Daniel Donoghue

developed as a refinement of the patterns or 'laws' observed in the earlier lays. 'The poets of the epic style', wrote Campbell, 'practised a more precise attention to the natural accentuation of their language than those of the lays. The most obvious result of this was avoidance of allowing a finite verb to alliterate in a half-line containing a noun, especially in the second half-line. ${ }^{5} 8$ While this alliteration is a license in a poem such as Beowulf it appears frequently enough in the Metres to be considered an acceptable usage. Other characteristics of the epic style, such as the strict adherence to Kuhn's First Law and the practice of alliteration only on the first stressed word of a half-line are more loosely observed in the Metres. It is an interesting possibility that the word order and stress of auxiliaries in the Metres are more evidence of a continuation of the tradition of the lays, and thus offer a positive and more objective means of identifying poems composed in that tradition. If this is the case, then one will not need to rely solely on more nebulous evidence like 'looseness' in the observance of metrical rules and the use of archaic vocabulary in order to decide if a poem can be considered part of the tradition of lays. Since this study has not undertaken to establish criteria by which lays may be distinguished from epics, it would be unwise to insist that the differences in word order outlined here are evidence that the Metres were composed as a late-ninth or early-tenth-century 'lay'. Continued existence of that tradition has yet to be established, and establishing it will require more work. If, on the other hand, it can be shown that other poems show a similar word order determined by the grammatical function of the clause, then it will provide solid evidence of variation within the Old English alliterative tradition. Perhaps one may then point to stress on auxiliaries in dependent clauses as a survival of an older practice, replaced in epic verse by the tendency to displace and stress auxiliaries on the basis of the number of unstressed particles at the beginning of the clause. Indeed, since in Vedic verse the verbs in subjunctive clauses are always stressed, the Metres poet's practice of stressing verbs in dependent clauses may testify not only to a late survival of early Germanic lays but also to a very ancient practice in Indo-European verse. ${ }^{59}$

58 Ibid. p. 16

59 See A. A. MacDonnell, $A$ Sanskrit Grammar (Oxford, 1975), pp. 243-4. Lehmann and Tabusa wrote, 'By the Indo-European and early Germanic linguistic practices, verbs of dependent clauses were stressed and might alliterate' (The Alliterations of the Beowulf, p. 6). I use Campbell's terms 'epic' and 'lay' for want of a better distinction. If the Metres belong to a different poetic tradition it may not be that of the 'lays' at all but some other. It is difficult to come to a definite conclusion on this matter because the evidence for lays is scanty. I have recently begun to examine auxiliaries and verbals in Cynewulf's four signed poems, where the auxiliaries do not behave quite as they do in the Metres or in Beowulf, but they more closely resemble the auxiliaries of the latter. Cynewulf may have been writing in the same tradition as that of Beowulf, or alternatively all three poets could represent three different individual variations of one 'classical' tradition. Indeed, all three poets shared a tendency to stress the
Word order and poetic style: 'The Metres of Boethius'

One final observation remains to be made in connection with verse syntax. It should be clear from the results presented here that it is useless to attempt to study verse syntax without a thorough acquaintance with the conventions of metre.60 Metre, because of the constraints it imposes on word order, is inextricably bound up with verse syntax. For instance, it can be considered a syntactic 'rule' that monosyllabic auxiliaries are restricted to the first half-line of the clause. ${ }^{61}$ In the Metres another 'rule' gives auxiliaries in dependent clauses a metrical stress. The combination of the two 'rules' limits the usual position of a monosyllabic auxiliary in a dependent clause to the last position of the first half-line, and indeed this location is where most such auxiliaries appear. It is more profitable to consider verse syntax as 'grammetrics' or 'metrical grammar', where words are judged not only for their grammatical function but also for their tôle in metre and alliteration. A recent article by Calvin Kendall 62 investigated how the scop's 'metrical grammar' worked to determine the position and stress of finite verbs in Beowulf. His methods and conclusions differ considerably from mine, but the differences should not obscure our fundamental agreement on the importance of considering verse syntax and metre together. Such an approach is more complex than, for instance, the study of prose syntax, but the subject of verse syntax has so far thwarted every simplification.

Some studies that otherwise have much to commend them have approached the problem of Old English verse syntax as if it were no different or only slightly different from prose syntax. ${ }^{63} \mathrm{This}$ approach makes little allowance for exceptional, 'rhetorical' usages in verse and for the distortions of syntax that inevitably accompany the constraints of a poet's 'metrical grammar'. Winfred P. Lehmann, in 'Proto-Germanic Syntax', ${ }^{4}$ recognized 'the difficulty that all the texts are literary' and that many are susceptible to the artificiality of metre. Nevertheless he went on to select examples from Beowulf and the runic verse inscription of the Gallehus horn in order to demonstrate OV word order in

auxiliary in a dependent clause. However, as I have shown, the Metres poet was more consistent in this pattern, and in Beowulf the stress appears to be the result of another tendency not related to grammatical function, as Bliss observed.

60 Kuhn's Laws, which locate the metrical dip at the beginning of the verse clause, are perhaps the most succinct expression of this relation.

62 'The Metrical Grammar of Beowulf: Displacement'.

63 E.g., Paul J. Hopper (The Syntax of the Simple Sentence in Proto-Germanic (The Hague and Paris, 1975), p. 56), applied Kuhn's conclusions for word order and stress in verse to his own examples from prose. In another study ('Old English as an SVO Language: Evidence from the Auxiliary', Papers in Ling. s (1972), 183-201) Lawrence Mitchell concentrated the bulk of his discussion on Old English prose, but concluded by applying his derivational process to verse.

64 Toward a Grammar of Proto-Germanic, ed. Frans van Coetsem and Herbert L. Kufner (Tübingen, 1972), pp. 39-68. 
Daniel Donoghue

Proto-Germanic. I do not have the space here to give Lehmann's important and judicious discussion the full attention it deserves. However, some of the dangers of treating verse syntax without regard to metre may be addressed by examining his conclusions on the word order of the Gallehus inscription: 'ek hlewagastiR holtijaR horna tawido'. He took the final position of tawido as evidence of the survival of archaic word order: 'On the basis of an inscription like that of Gallehus ... we may propose an OV order for the PGmc. sentence.' Later he associated this word order with the 'archaic language' of Beowulf: 'As in the Gallehus inscription, finite verbs are avoided in the first three metrical lifts, and accordingly they are generally found in the final position of the metrical line, in accordance with a basic OV order'. ${ }^{65}$ It is true that the end-position of tawido coincides with the early word order OV, but does it demonstrate that the 'basic' word order survived? Is it not equally possible that the position of the verb was determined more by metrical rules (contemporary to blewagastiR) than by archaic syntax? If, for example, Sievers's Rule prescribes the final position of tawido, it may provide indirect evidence that such a word order in non-poetic discourse once existed, but not necessarily. Perhaps the 'accordance' that Lehmann notes between the Gallehus word order and the early OV order is accidental. We simply do not know the extent to which the rules of metre preserved the syntax of early nonpoetic discourse and the extent to which their formation was the result of arbitrary choice. The existence of a particular word order in verse is not convincing evidence of archaic syntax when the word order may be satisfactorily explained on the basis of metrical rules. What must be shown before such a claim can be made is that the rules of metre derived from archaic syntax, and this is a much more difficult undertaking.

This caveat, however, should not be taken to imply that prose syntax and verse syntax are unrelated. Most students of the field would agree with Bliss that 'in spite of obvious differences, there is a great deal in common between verse syntax and prose syntax. It seems most probable that there is a fairly close relationship between the two: one may be derived from the other, or alternatively both may be derived from the same original system by different modifications of it.' ${ }^{66}$ While Bliss's observation may hold true, a number of complications obscure the essential similarity of prose and verse word order. It would be a mistake, for instance, to believe that verse is merely prose rearranged to suit conventionally established rhythmical patterns, resulting in a distortion of 'normal' word order (and this is far from Bliss's position). On the one hand, Germanic verse is of great antiquity and almost certainly

65 Ibid. pp. 243 and 244. He was certainly aware of the metrical form of the inscription; see his comments, The Development of Germanic Verse Form (Austin, Texas, 1956), pp. 28-9.

66 'Auxiliary and Verbal', pp. 173-4.
Word order and poetic style: 'The Metres of Boethius'

influenced the first authors of Old English prose. ${ }^{67}$ Prose itself can be highly stylized; its degree of artificiality falls somewhere between the (presumed) freedom of spoken Old English and the carefully wrought half-lines of classical verse. On the other hand, this study has shown how a poet's metrical grammar can account for what Bliss called the 'obvious differences' between prose syntax and verse syntax. The poet had to balance a variety of constraints and often found it necessary to disregard rules of simple syntax in favour of other considerations such as Kuhn's laws, which govern both metre and syntax. A prose author might use the same poetic devices but was never bound by them. Moreover, since the earliest prose authors were trained in the church, the influence of Latin on the syntax of Old English prose, however indeterminable, is undeniable. Consequently it is difficult if not impossible to arrive at an exact conclusion regarding the relation of prose to verse.

In the particular case of the Old English prose and verse translations of Boethius the complications increase even more. One cannot disregard the possibility that some Latin influence on the prose model was carried over to the verse, or that a more general verse influence on the prose was received back by the verse. One advantage of the method adopted in this study is that nonpoetic usages show up as exceptions to the usual patterns, no matter what their origins may have been. The distinction between prose and verse is particularly strong in the case of auxiliaries, which are affected by a variety of poetic conventions. For example, the Metres poet observed the 'rule' of stressing the auxiliary in dependent clauses, a constraint that did not apply to the author of the prose model. Other constraints such as Kuhn's two laws, Sievers's Rule

${ }^{67}$ See Campbell, 'Verse Influences in Old English Prose'. The rhythmical influence of verse on prose has received a greater amount of scholarly attention. Dorothy Whitelock ('The Prose of Alfred's Reign', Continuations and Beginnings: Studies in Old English Literature, ed. Eric G. Stanley (London, 1966), pp. 67-103, esp. 98-101) discussed the varying degrees of stylization found in prose at the time of Alfred's translation of Boethius, though she did not directly deal with the possibility of verse influence on the prose. Otto Funke ('Studien zur alliterierenden und rhythmisierenden Prosa in der älteren altenglischen Homiletik', Anglia 80 (1962), 9-36) found a tradition of alliteration and rhythmical phrasing already present in prose well before Ælfric and Wulfstan. An important study by Angus McIntosh ('Wulfstan's Prose', PBA 25 (1949), 109-42) outlined five rhythmical ways of writing that extend from 'classical' Old English verse to 'ordinary prose' and noted similarities between 'debased verse' and rhythmical prose. His conclusions on Wulfstan's rhythmical prose have recently been challenged by Ida Masters Hollowell ('On the Two-Stress Theory of Wulfstan's Rhythm', $P Q 6 \mathrm{r}(\mathrm{r} 982), \mathrm{I}-\mathrm{Ir}$ ), who argued that larger syntactical units rather than two-stress phrasing are the organizing principle of Wulfstan's prose. By comparison, Elfric's rhythmical prose, as John C. Pope explained in the introduction to his edition of Ælfric's homilies, more closely approximates to the rhythm of 'classical' Old English verse (Homilies of Elfric: a Supplementary Collection, 2 vols., EETS 259-60 (London, 1967-8), 105-36). Where such extensive metrical influence is present, it seems plausible that there is also some syntactic influence of verse on the prose. 


\section{Daniel Donoghue}

and the restriction of monosyllabic auxiliaries to the first half-line of a clause make the auxiliary an exceptionally effective indicator of how the poet's 'metrical grammar' can obscure the originally close relation between the word orders of prose and verse. The differences between the Metres and its prose model are especially striking, because they are so similar in other respects. Indeed, while the poet remained quite close to the literal meaning of the prose text, he deliberately set out to 'translate' it into the language of poetry. From a technical point of view he was successful. (The aesthetic quality of his verse is another matter.) A more recent poet, Robert Frost, has described the language of poetry as that which is lost in translation, but in these two Old English texts an opposite process has taken place. Poetry is what has been gained in the 'translation' from prose to verse.

\section{A third Old English translation of part of Gregory's Dialogues, this time embedded in the Rule of Chrodegang}

\author{
BRIGITTE LANGEFELD
}

Gregory's Dialogues are a hitherto unnoticed source of the final chapter of the enlarged version of the Rule of Chrodegang of Metz. ${ }^{1}$ The chapter in question, no. 84 or 86 depending on the recension of the Latin text, ${ }^{2}$ is preserved in the following manuscripts (the letters in brackets are the sigla used for these manuscripts throughout this article):

Paris, Bibliothèque Nationale, lat. $1535(\mathrm{P}), \mathrm{I} 13 \mathrm{~V}-149 \mathrm{~V}$. Second quarter of the ninth century, possibly written at Fécamp. Latin text only, 86 chapters. ${ }^{3}$

Brussels, Bibliothèque Royale, $8558-63$ (B), Ir-38v. First half of the tenth century, probably from south-east England. Latin text only, chs. 10-84 complete (chs. I-4, 7 and 8 lost and chs. 5, 6 and 9 incomplete). ${ }^{4}$

Cambridge, Corpus Christi College 191 (C), pp. 1-169. Third quarter of the eleventh century, written at Exeter. Latin text and Old English translation, 84 chapters. ${ }^{5}$

1 I am grateful to Professor Helmut Gneuss and Dr David Dumville for their help and critica suggestions when they read the first draft of this article.

2 See B. Langefeld 'Die lateinische Vorlage der altenglischen Chrodegang-Regel', Anglia 98 (1980), 403-16, at 406-8, and 'Die Chrodegang-Regel in England. Lateinischer Text und altenglische Ubersetzung' (unpubl. Ph.D. dissertation, Univ. of Munich, 1985), pp. 25-7. 3 For previous editions, see J. P. d'Achery, Spicilegium Veterum Aliquot Scriptorum I (Paris, 1 723), $565-83$, and, following that edition, ed. J. P. Migne, Patrologia Latini 89 , cols. 1057 6. For information on this manuscript, see L. Delisle, Bibliotheca Bigotiana Manuscripta (Rouen, 1877), p. 28, and P. Lauer, Bibliotbeque Nationale. Catalogue des manuscrits Latins 1

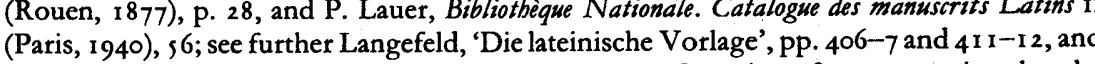
'Die Chrodegang-Regel in England', pp. 25-7. For a confirmation of my suggestion that the manuscript was very likely written at Fécamp, cf. B. Branch, 'Inventories of the Library of Fécamp from the Eleventh and Twelfth Century', Manuscripta 3 (1979), 1 59-72, at 161-2.

4 No previous edition. For information on the manuscript, see N. R. Ker, Catalogue of Manuscripts containing Anglo-Saxon (Oxford, 1957), no. Io (A), and J. van den Gheyn Catalogue des manuscrits de la Bibliothèque Royale de Belgique Iv (Brussels, 1904), no. 2498; cf. Langefeld, 'Die Chrodegang-Regel in England', pp. 32-3.

5 For the only previous edition, see The Old English Version of the Enlarged Rule of Chrodegang togetber with the Latin Original etc., ed. A. S. Napier, EETS o.s. 150 (London, 1916 ; repr. New York, 1971). For information on the manuscript, see Ker, Catalogue, no. 46; see further E. 